\title{
Study on the Landfill Technology of the Rural Living Garbage Ecological Sanitary
}

\author{
Zhang Xiaoyi \\ XinYu University, XinYu ,China, 338004
}

Keywords: Sanitary Landfill ; Ecological Landfill; Process Principle; BOD; COD

\begin{abstract}
At present, sanitary landfill method is used in most towns and cities to handle the garbage . The technology is relatively simple, reliable, economical and easy to operate and manage. Ecological landfill is a new method of the landfill based on the development of foundation. This paper aims to explore and discuss the process of ecological sanitary landfill, with relevant design and management personnel.
\end{abstract}

\section{Introduction}

Along with the rapid growth of rural economy and society, the level of people's material life is unceasingly enhanced, and the quantity of the rural garbage continues to increase, phenomenon that sewage and garbage is thrown and dumped everywhere is visible, and the pollution problem is getting serious,which threatens people's health .Furhermore, many of the rural collected and transported garbage is thrown bare on the earth, and only a part of them are covered by thin earth, without any waste harmless handling, which does great harm not only to environmental quality, lead to environmental pollution, and arouses great dissatisfaction of surrounding residents.

There are a variety of life garbage disposal methods at present, the commonly used are mainly sanitary landfill, incineration, composting and recycling synthesis processing method. No matter what way of disposal, its purpose is to make the living garbage reduction, harmless and recycling.

\section{The Present Situation of Living Garbage Processing}

Currently, the disposal method living garbage for is the simple landfill, the waste is naturally stacked after spraying flykiller on the surface, and is covered by earth 2 times a week. This simple stacked way causes serious environmental problems such as the flies breeding, sewage diffuser, which is unable to meet the needs of urban development. Therefore, the construction of harmless landfill is imminent.

\section{Comparisons Of Ways Of Garbage Disposal}

There are a variety of life garbage disposal methods at present, the commonly used are mainly sanitary landfill, incineration, composting and recycling synthesis processing method. No matter what way of disposal, its purpose is to make the living garbage reduction, harmless and recycling.

The Sanitary Landfill. Sanitary landfill is a kind of engineering work dealing with garbage, which is not harmful to the environment. So this process needs careful and perfect design, refined construction, and effective operation management. The basic approach is to junk shop with a certain thickness, compaction, and then every day covered by earth, and minimize the environmental pollution. It is the final disposal sites of garbage, will co-exist for a long time with the waste treatment process.

The sanitary landfill technology started in the 1930s, all countries has accumulated rich experience, and developed a complete set of technology and equipment in the planning, designing, construction, and management of sanitary landfill after 60 years research and development, . At present, the sanitary landfill is still widely used and is the main disposal method in many countries and regions of the world. 
Compared with other methods, the characteristic of sanitary landfill method is: advantages: (1) less investment, low operation cost; (2) the impact resistant load capability, which is not affected by the growth of the waste ; (3) possible recycling resources, including the development of biogas recovery energy, landfill and stretched out land combined, the stability of landfill is recycled as land resource . Defects of Sanitary landfill : (1) location is difficult, and the site is often far away from city center, and the cost of transportation is increased; (2) garbage harmless time is long, it is easy to cause secondary pollution with good management; (3) leachate treatment is still a difficulty.

Incineration. The Incineration technology began in the late 19th century, but it was not widely used until the 1960s. It is characterized by: (1) high degree of harmlessness, high decrement (weight can be reduced by $70 \%$, the volume can be reduced by more than 90\%); (2) short processing period; (3) recovery of heat or electricity; (4) low need to site requirement, small cover of land. The incineration technology's deficiencies are: (1) high cost of investment operation; (2) requirements of the calorific value of garbage disposal; (3) serious secondary pollution, such as flue gas, fly ash, slag, dioxin which all need effective measures to control.

Compost. Some countries in Europe began to use composting technology to process large scale waste in the 1930s. Composting method is a main way to realize the dream that the waste is recycled and reduced in urban areas. The process is divided into aerobic compost and anaerobic composting according to the condition of oxygen. The two processes have different characteristics.

Anaerobic composting is under the condition of no oxygen, which accumulates organic matter on anaerobic fermentation, organic fertilizer, and makes solid waste harmless. Its advantages are: (1) easy operation; (2) less investment and energy consumption, generally used in vast rural. Disadvantages: (1) long time for rotten and free-pollution, difficulty in large processing; (2) wide landcover, bad smell; (3).ineffectiveness of harmlessness.

Aerobic composting is under aerobic conditions, the process is to use microbial decompose organic matter and the stabilization. There are many kinds of aerobic composting process, but the process generally includes pretreatment, a fermentation, filtration, secondary fermentation, sorting, packaging molding, etc. And with the development of the technology research, the mechanized equipment is generally adopted. In recent years, the developed countries on the one hand control the quantity of the landfill of the waste, and on the other hand strongly advocate and promote high temperature compost method. Its advantages are: (1) short composting period; (2) small odor pollution, (3) better harmless effect. Its deficiencies lie in: (1) high cost; (2) products are great influenced by the market; (3) certain requirements of compost rubbish.

\section{Explore To Ecological Sanitary Landfill Technology}

Introduction of The Concept. Ecological landfill is a new way of landfill developed on the basis of sanitary landfill. Both ecological landfill and sanitary landfill have the same impermeable layer, but the difference is that the sanitary landfill is the waste isolation, isolated (pollutants) and the environment has become a closed system of segregation, but the ecological environment is in succession of sanitary landfill isolation means, on the basis of the landfill as a relatively independent ecological transformation system, maximize the conversion or fixed solid waste produced by the pollution substances.

Guiding Ideology Of Ecological Landfill. According to urban life garbage which contains carbon organic matter, nitrogen organic matter and heavy metal pollution, landfill site isolation facilities use the relatively independent ecological space, and at the same time landfill layer by the anaerobic metabolism of anaerobic microbial communities to form the ecological plants of reaction layer and the coverage of vegetation and soil formation of the ecological zone, as a carbon source organic matter can be converted to energy recovery of methane and nitrogen source after hydrolysis of ammonia nitrogen organic matter absorbed by the plant into a material, heavy metals in landfill layer and reducing sulfur and carbonate ions combine to stabilize insoluble metal compounds. Inherent in elimination of waste in the form of ecological factor reduced the harm of environmental pollution. 
Characteristics Of Ecological Landfill. Firstly, landfill waste biodegradation process should be regulated, through which, using the layer within a biological process for accelerated degradation, garbage leachate purification treatment, so the purpose of resource transformation (burning landfill gas) can be reached; Secondly, ecological landfill also uses the vegetation layer of soil/vegetation system transformation ability to reach the reduction of leachate pollutants of tail water (via infusion with water) inside the water, the purpose of the removal of nutrients into a material. So passive isolation and sanitary landfill pollution control concept are different, the ecological landfill emphasizes the main degradation and transformation of pollution, and the degradation and transformation of space is enclosed by the isolation measures of modern landfill space, its core is the use of landfill space ecological transformation ability. Ecological landfill contains more effectively active ability to collect and use gas, and utilize the waste resources instead of disposable materials for operating technique.

\section{4, Advantages of ecological landfill}

Compared with the traditional structure of sanitary landfill, the ecological landfill increased the leachate recycling system, and reformed the leachate collection system and landfill gas collection system. Compared with sanitary landfill, it has the following advantages: (1) reduce the pollution of leachate and leachate water is stable; (2) accelerate the degradation, shorten the stabilization period of garbage; (3) speed up the settlement of landfills, increase the effective database of landfill; (4) speed up the landfill layer into the methane-producing phase, improve methane production rate and gas production, make the gas concentration, (5) shorten the landfill closure after field maintenance and management time, venue reuse in advance,(6) reduce landfill disposal costs.

The Process Principle Of Ecological Landfill. After the fresh waste is covered, in brief after the aerobic stage, intraformational enters acidifying fermentation stage, at this point, the organic matter in waste fermentation will produce mainly VFA soluble ingredients, which makes the $\mathrm{pH}$ inside the layer into the acidification condition $(\mathrm{pH}<5.5$ ), resulting in outflow of leachate organic load increase, intraformational methanation microbes cannot grow, leachate unable to achieve the purpose of reducing pollution load cycles.

Experiments show that eliminating acid (mainly VFA) accumulation in two different ways: one is to supply a small amount of air inside, which can make excess VFA by oxidation pathways into CO2 and $\mathrm{H} 2 \mathrm{O}$, and eliminate layer in acid accumulation, and develop the methanation metabolism. Secondly, it is the leachate pretreatment and then recycling. After pretreatment of leachate COD, VFA concentration is reduced, and the $\mathrm{pH}$ value increases, and it is cycled to the landfill, the acid environment within the local will change in some way, and finally from the point source to expand outside, making corresponding area to promote methanation metabolism.

Experiments show that after 2 months, a small amount of ventilation the $\mathrm{CH} 4$ content is greater than $30 \%$, LFG inside the leachate $\mathrm{pH}>6.0$, organic load is significantly reduced, and the landfill layer goes into the methanation stage, and through the loop to reduce leachate organic load, will be converted to use of landfill gas (LFG) ability. Landfill leachate pretreatment cycle, stable layer of methanation metabolic conditions can be established after 3 months.

The first kind of way of methane metabolism is mainly from down to up, the second way is from top to bottom. Status due to the project site in simple landfills, this part of the rubbish piled up in the fixed number of year is longer (up to 6 years), the stabilization stage has been reached. So people can directly use the partial stabilization of garbage landfill layer as a first step.

Litter layer after a period of methanation metabolism after reaching preliminary stability (leachate $\mathrm{pH}$ value of 7.0 or higher, COD $<5000 \mathrm{mg} / \mathrm{L}$ ), stop leachate pretreatment, but ongoing leachate circulation and restore intermittent trace ventilation, it can make the circulation of the NH3 $\mathrm{N}$ in aerobic zone in the leachate is nitration of NO2 - / NO3 -, in the absence of denitrification for N2 molecular oxygen area, achieve the purpose of through circulation purification nitrogen pollution.

Implementation Steps Of Sanitary Landfill Technology. Waste sanitary landfill operation is different from the open-air stacking. In order to guarantee the effect of sanitary landfill, landfill operation should strictly abide by the relevant processes and other technical requirements. At the 
same time, the ecological landfill is sanitary landfill process improvement; in the process also need to follow the requirements of sanitary landfill.

(1) Garbage entry records

Landfills withstand credible depends on accurate allowance into garbage record. The best way is to set a scale to balance imported vehicles. In addition, according to the garbage record a landfill site development plan can also be made.

(2) Landfill

Landfill operation unit executes partition layer operation, according to the sequence and cycle. Waste discharged into the landfill areas first and then carried out by a bulldozer paving, landfill unit size calculation is based on the work of the day. Each unit body dump height is $3 \mathrm{~m}$, divided into 2 3 roller compacted layer. Each roller compacted layer thickness is about $1.0 \sim 1.5 \mathrm{~m}$.

(3) Compaction

To increase landfill capacity, and ensure the possibility of waste transport vehicles are driven in the landfill body surface, after waste material smooth, configuration landfill garbage compactor to compaction, the compaction garbage after density reached $0.9 \mathrm{t} / \mathrm{m}$. Garbage after completion of discharging, bulldozers to bulldoze the garbage to the whole area, then use steel wheel compaction compaction machine immediately.

Garbage compaction adopts the method of hierarchical compaction, after compaction of each layer thickness is $500 \mathrm{~mm}$, every day working in the unit will be $4 \sim 5$ layer hierarchical compaction, the compaction machine pressure on each layer 3 times at least. Specific compaction method is, first of all, will loose garbage into the layer thickness is about $1 \mathrm{~m}$, paving and compaction machine pressed loose garbage actually realized the thickness is less than $500 \mathrm{~mm}$ and the desired density.

(4) The cover of garbage

To control odor, reduce the wind sand and debris (such as paper, plastic, etc.), the landfill waste layer (divided into cover and end cover) must be carried out. Daily landfills must be covered $20 \sim 30$ cm thick after compaction, cant cover soil must be $10-15 \mathrm{~cm}$; compaction operation is required to pass through. The final landfill sealing field should on landfills covered a layer of $30 \mathrm{~cm}$ thick, the permeability coefficient is not more than $10-7 \mathrm{~cm} / \mathrm{s}$ clay, again on the cover of $45 \sim 50 \mathrm{~cm}$ thick natural soil, and uniform compaction. Layered completes the anti-seepage, finished with artificial, geotextile, clay seepage control layer, reduce the amount of leachate to the largest extent. For garbage covered, bulldozers, excavators and loaders that need to be equipped with necessary equipment, used in mining, landfill, and compaction fabrics, to ensure the quality of the landfill.

(5) Green

Upon final covering add about $15 \mathrm{~cm}$ nutritional soil, green operations again.

\section{Requirements of Sanitary Landfill Site}

(1) Clear functional partition. According to the needs of landfill processes and management, rational division of the landfill area , production and living district, processing facilities area, soil area, each partitioning feature clear, reasonable arrangement are all required.

(2) Adjust measures to local conditions. The importance is reasonable use of terrain, as far as possible to do earthwork balance, reduce the quantity of construction conditions, save construction investment.

(3) Improve the occasion. It is important to rain sewage diversion which is advantageous for the landfill operation and implementation, the landfill area is divided into two landfill areas, with the middle dam separates, and installment construction. To combine the terrain at the same time, take the necessary cutting flood, flood control measures, minimize soil erosion, and reduce rainwater into the landfill area, thereby reducing discharge leachate.

(4) Green segregation. The overall layout should be considered in the landfill area, set up necessary isolation belt, green in the landfill and roads on both sides of the area surrounding slope, along with landfill slope greening on the formation of green barriers. 
(5) The landfill area layout should not only consider the rationality of the site construction, but also consider leachate collection and biogas collection, in order to save energy.

\section{Conclusion}

Handling of solid waste, whether the incineration, composting and sanitary landfill method, or land patch, will more or less play some negative effects on the surrounding ecological environment. Handling of the ecological problems of landfill, can not only make full use of ecological restoration and ecological improvement of technology, but also can work harder in the aspect of institutional innovation. However, the system innovation is conducive to the specification from the aspects of system's handling of urban solid waste problems, and targeted on the lack of technology. Therefore, only the two are combined, will the effect be better.

\section{References}

[1] Wupeng Du, Qingxian Gao, Enshen Zhang,etc. Analysis Field of China City Life Garbage Disposal andTrend Environmental Science Research，2006,19(6):1l5-120

[2] Guangliang Yan, Shancai Zhao Analysis on the city living garbage processing technology characteristics and development trends. Environmental health engineering,2011,19(3):32-33.

[3] Gao Hai. Municipal solid waste sanitary landfill design theory and application research. Hunan University,2004.

[4] Daqing Pan Dashuan Yang, Aijun Li Study on AsuWei waste sanitary landfill closed landfill technology Urban management and technology , 2011 ,3 (5) 54-56.

[5] Liming Shao, Jisheng zhong, Houhu Zhang, Living garbage landfill CHQ release in spring and summer And influencing factors of the field Environmental Science Research , 2009,22(1):83-88.

[6] Yuqiang Liu, Qifei Huang, Wang Qi Living Gabage Landfill Environmental pollution and prevention ,2005,27(5):333-337.

[7] Lihua Gong, Living garbage landfill landfill gas discharge estimation model [J].,2009 